\title{
AUGUST 1971
}

\section{ELEVENTH YEAR - No. 125}
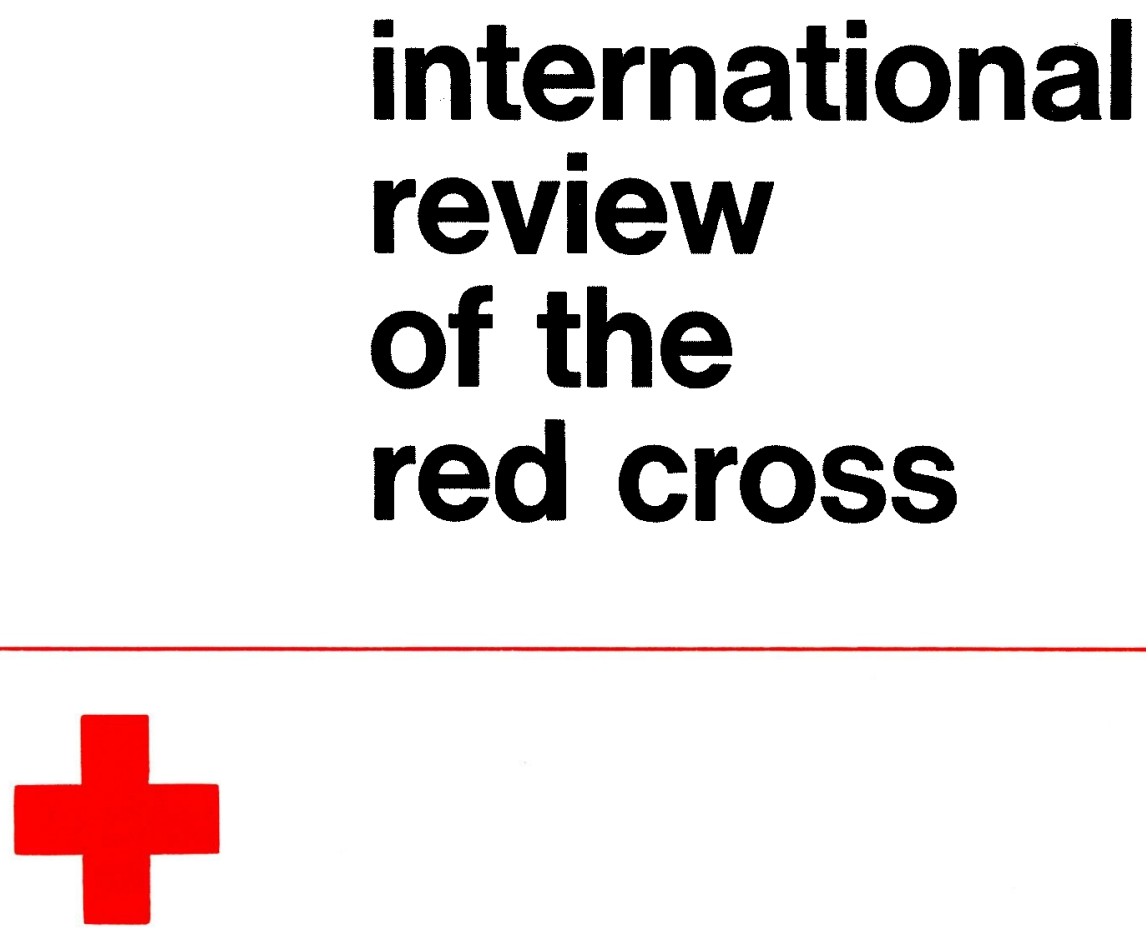

INTER ARMA CARITAS

GENEVA

INTERNATIONAL COMMITTEE OF THE RED CROS FOUNDED IN 1863 


\section{INTERNATIONAL COMMITTEE OF THE RED CROSS}

MARCEL A. NAVILLE, President (member since 1967)

JEAN PICTET, Doctor of Laws, Chairman of the Legal Commission, Vice-President (1967)

HARALD HUBER, Doctor of Laws, Federal Court Judge, Vice-President (1969)

PAUL RUEGGER, Ambassador, President of the ICRC from 1948 to 1955 (1948)

GUILLAUME BORDIER, Certificated Engineer E.P.F., M.B.A. Harvard, Banker (1955)

HANS BACHMANN, Doctor of Laws, Winterthur Stadtrat (1958)

JACQUES FREYMOND, Doctor of Literature, Director of the Graduate Institute of International Studies, Professor at the University of Geneva (1959)

DIETRICH SCHINDLER, Doctor of Laws, Professor at the University of Zurich (1961)

MARJORIE DUVILLARD, nurse (1961)

MAX PETITPIERRE, Doctor of Laws, former President of the Swiss Confederation (1961)

ADOLPHE GRAEDEL, member of the Swiss National Council from 1951 to 1963, former Secretary-General of the International Metal Workers Federation (1965)

DENISE BINDSCHEDLER-ROBERT, Doctor of Laws, Professor at the Graduate Institute of International Studies (1967)

JACQUES F. DE ROUGEMONT, Doctor of Medicine (1967)

ROGER GALLOPIN, Doctor of Laws, former Director-General (1967)

WALDEMAR JUCKER, Doctor of Laws, Secretary, Union syndicale suisse (1967)

VICTOR H. UMBRICHT, Doctor of Laws, Managing Director (1970)

PIERRE MICHELI (1971)

Honorary members: Mr. JACQUES CHENEVIERE, Honorary Vice-President;

Miss LUCIE ODIER, Honorary Vice-President; Messrs. CARL J. BURCKHARDT, PAUL CARRY, Mrs. MARGUERITE GAUTIER-VAN BERCHEM,

Messrs. SAMUEL A. GONARD, ÉDOUARD de HALLER, PAUL LOGOZ, RODOLFO OLGIATI, FREDERIC SIORDET, ALFREDO VANNOTTI, ADOLF VISCHER.

Directorate: Mr. JEAN-LOUIS LE FORT, Secretary-General.

Mr. RAYMOND COURVOISIER, Special Assistant to the President and Director of Operations.

Mr. CLAUDE PILLOUD, Director, Department of Principles and Law. 


\section{INTERNATIONAL REVIEW OF THE RED CROSS}

AUGUST 1971 - No. 125

\begin{abstract}
INTERNATIONAL COMMITTEE OF THE RED CROSS
\end{abstract}

IN THE RED CROSS WORLD

\section{MISCELLANEOUS}

BOOKS AND REVIEWS
S. Raine : Nursing Problems - The Nurse-Patient Relationship $\ldots \ldots \ldots \ldots \ldots \ldots \ldots \ldots \ldots$

External Activities :

Japan - Khmer Republic - Republic of Vietnam Bulgaria - Near East - Yemen Arab Republic India and Pakistan .................. 428

In Geneva :

For Victims of Pseudo-Medical Experiments... 432 ICRC Relief Action ............... 432

An ICRC Delegate in Ceylon ............. 435

The "Soldier's Manual » ................. 439

World Red Cross Day $1972 \ldots \ldots \ldots \ldots \ldots \ldots .441$

International Red Cross Museum .......... 441

Fourth Varna Film Festival ............. 442

Red Cross and the Environment.......... 446

France ......................... 447

Assistance in Natural Disaster and Other Emergency Situations $\ldots \ldots \ldots \ldots \ldots \ldots \ldots \ldots \ldots \quad 450$

The Neutrality of a XVII Century Field Hospital. . 454

The Basic Hospital's Function ........... 459 
FRENCH EDITION

OF THE REVIEW

\section{SUPPLEMENTS \\ TO THE REVIEW}

SPANISH

GERMAN

INTERNATIONAL

REVIEW OF

THE RED CROSS
The French edition of this Review is issued every month under the title of Revue internationale de la Croix-Rouge. It is, in principle, identical with the English edition and may be obtained under the same conditions.

Las «Memorias» de Henry Dunant - Reafirmación y desarrollo del Derecho internacional humanitario aplicable en los conflictos armados : Conferencia de expertos gubernamentales - Un balance positivo - El «Manual del Soldado".

J. Patrnogic : Medizinisches Völkerrecht (Die neuen Tendenzen) - Neubestätigung und Weiterentwicklung des in bewaffneten Konflikten anwendbaren humanitären Völkerrechts : Regierungsexpertenkonferenz (Eine positive Bilanz).

The International Review is published each month by the International Committee of the Red Cross

7, avenue de la Paix, 1211 Geneva I, Switzerland Postal Cheque No. 121767

Annual subscription: Sw. fr. 25.- (\$6)

Single copies Sw. fr. $2.50(\$ 0.60)$

Editor: J.-G. LOSSIER

The International Committee of the Red Cross assumes responsibility only for material over its own signature. 